\title{
В.В. Броварник ${ }^{1}$, T.М. Головач²
}

${ }^{1}$ Научно-учебньй чентр прикладной информатики НАН Украины, пр. Академика Глуиккова, 40, Киев,

${ }^{2}$ Институт микробиологии и вирусологии им. Д.К. Заболотного НАН Украины, ул. Заболотного 154, Киев ГСП, Д03680

\section{БАЗА ДАННЫХ ДЛЯ ДЕПОЗИТАРИЯ КУЛЬТУР МИКРООРГАНИЗМОВ}

\begin{abstract}
Разработана с использованием СУБД МS Access 2010 база данных (БД) депозитария культур микроорганизмов. Ядро БД состоит из трех основных модулей: общего описания, администрирования, сохранения. Приводится описание информачии, которая содержится в каждом из этих модулей, для решения характерных для ведения депозитария задач. На основе Бд разрабатывается вебстраница депозитария.
\end{abstract}

Ключев в е слов в: микроорганизмы, коллекция, депозитарий, база данныхх.

Приметой нашего времени стало осознание огромного биологического разнообразия окружаюшего нас мира и понимание необходимости сохранения этого разнообразия в природных условиях in situ и еx situ [2].

В мире существует много коллекций культур микроорганизмов. Только во Всемирном центре данных по микроорганизмам - World Data Center for Microorganisms (WDCM) Всемирной федерации культур - World Federation for Culture Collections (WFCC) зарегистрировано свыше 600 коллекций из более 70 стран. Такие коллекции служат ресурсной базой для научных исследований, патентования, биотехнологической промышленности, медицины, сельского хозяйства, экологии.

Коллекции информируют общественность о микроорганизмах, которые находятся у них на хранении. Объем такой информации бывает разным. Большинство коллекций предоставляет минимальный объем информации - только перечень типов, родов, видов, а иногда и подвидов микроорганизмов. Другие публикуют каталоги культур микроорганизмов, а некоторые крупные коллекции и биоресурсные центры еще дополнительно предоставляют большие списки литературных ссылок, которые имеют отношение к их коллекционному материалу.

Эффективному ведению коллекционного дела служит специализированное программное обеспечение, которое используется такими базами данных.

Разработано базу данных для информации, которая предназначена для депозитария культур микроорганизмов.

Условно информация, что составляет ядро этой базы данных, разбита на три блока: общего описания, администрирования, хранения (рис.1).

В блоке общего описания сосредоточена информация общего плана относительно штаммов микроорганизмов. Большая часть этой информации имеется в паспорте и справке о непатогенности и предоставляется самим депозитором во время процедуры депонирования $[4,5]$. 


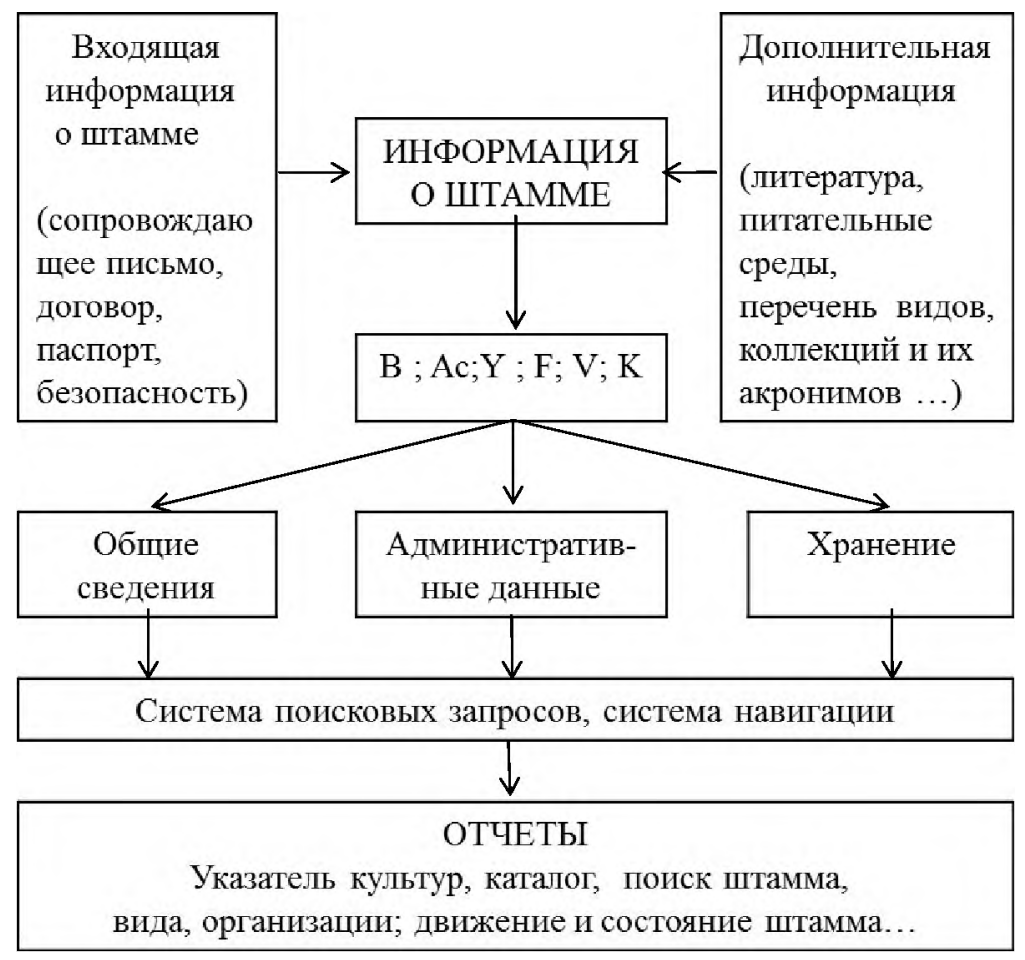

Рис. 1. Структура базы данных.

Принятое в базе данных таксономическое описание штаммов микроорганизмов имеет трехуровневую древовидную иерархическую структуру. На верхнем уровне иерархии находятся таксономические групшы (типы) микроорганизмов. Так, в депозитарии Института микробиологии и вирусологии им. Д.К. Заболотного НАН Украины (IMB) работают с такими таксономическими группами как бактерии, в частности, актиномицеты и микроскопические грибы, в отдельности, дрожжи, вирусы, консорциумы (ассоциации). Средний уровень иерархии занимают роды, виды и подвиды. Нижний уровень иерархии составляют штаммы микроорганизмов.

В блоке общего описания сохраняются не только авторское название вида культуры и номер или наименование штамма микроорганизма, но и те, что присваиваются администрацией депозитария.

При депонировании администрация депозитария может согласиться с указанным в паспорте видовым названием или провести дополнительные исследования. Если в случае проведения дополнительных исследований выявится несоответствие реального видового названия культуры заявленному в паспорте штамма, то администрация депозитария примет новое уточненное видовое название. Для каждого видового названия, принятого администрацией депозитария, фиксируется его валидность.

Поскольку у одного вида может существовать несколько названий, как исторических устаревших, что постепенно вышли из широкого употребления, так и современных, то эти синонимические названия также сохраняются в базе данных. Наличие и авторского, и присвоенного администрацией депозитария и синонимического видового названия культуры микроорганизма расширяет поисковые возможности пользователя. 
При депонировании администрация депозитария каждому штамму микроорганизма присваивает свой идентификатор (номер). Так, в коллекции депозитария ИМВ (IMB укр.) первые три буквы в начале идентификатора указывают аббревиатуру коллекции, далее после пробела идет тип микроорганизма, дефис и порядковый номер штамма. Например, IMB B-7003 - идентификатор штамма бактерии, а IMB F-100002 - идентификатор штамма гриба.

В разных коллекшиях микроорганизмов и в Украине, и за ее пределами один и тот же штамм может иметь разные номера, так как единой номенклатуры идентификаторов штаммов микроорганизмов не существует. Например, штамм IMB B-7190 из коллекции депозитария ИМВ в коллекции National Collection of Industrial and Marine Bacteria имеет номер NCIMB 11775, а в коллекции Czech Collection of Microorganisms - CCM 1914. В случае известия о наличие штамма в иной коллекции - информация о такой коллекции и присвоенный там идентификатор штамма сохраняется в базе данных.

Обычно помечаются штаммы, которые есть типовыми для вида.

Представлена предыстория поступления штамма в депозитарий, на каждом этапе которой сообщается место нахождения штамма и идентификатор, который ему там был присвоен.

Большой объем информации касается морфолого-культуральных и физиолого-биохимических свойств культур микроорганизмов, которые могут использоваться при их идентификации.

Описание штамма содержит также информацию о дате, месте и источнике его изоляции, а для мутантных культур - приводятся номер материнского штамма и метод селекции.

Указывается предназначение штамма микроорганизма, т.е. направления его применения, такие как патентный, промышленный, тест-культура, учебный, референтный, специальный. Приводятся примеры практического использования штаммов микроорганизмов в разных областях человеческой деятельности.

Фиксируется группа патогенности штамма микроорганизма. Депозитарий ИМВ является единственным в Украине, который проводит депонирование непатогенных микроорганизмов и может работать с микроорганизмами III-IV групп опасности [6].

Для штаммов, депонированных с целью патентования, при возможности фиксируются основные этапы прохождения патентной процедуры. Собирается информация о стране и организации, куда подается заявка, дате подачи, номере и названии заявки, дате выдачи патента, его номере и названии, коде патента в соответствии с Международной патентной классификацией (МПК) - International Patent Classification.

Стоит упомянуть и источники информации, на которые делаются ссылки в базе данных. Это книги, журнальные статьи, патенты, заявки на патент, авторские свидетельства, нормативные акты, технические условия.

Информация, которая касается процедуры депонирования штаммов микроорганизмов и предоставления сервисных услуг, находится в блоке администрирования базы данных.

Там сохраняются ведомости о депозиторах, условиях депонирования и договорных обязательствах сторон, а также перечень предоставленной при депонировании сопроводительной документации.

Депозиторами в депозитарии могут быть как юридические, так и физические лица. В депозитарии ИМВ депонировать штаммы могут сотрудники ИМВ и 
внешние депозиторы. Все их реквизиты, которые помечены как обязательные, остаются в базе данных.

Существуют случаи, когда один штамм микроорганизма депонируется несколькими депозиторами вместе или один договор касается нескольких штаммов. Возможны и договоры, в которых говорится о депонировании несколькими депозиторами нескольких штаммов. В случае, когда депозитором является юридическое лицо, также могут быть представлены персональные данные авторского коллектива сотрудников, ответственных за штамм.

Кроме депозиторов в договорах указаны номер договора, дата его подписания, начальная и конечная даты хранения штамма в депозитарии, стоимость услуги и т.д.

Для каждой сервисной услуги, которая предоставляется депозитарием, рекомендована информация для сохранения в базе данных. Обработка заявок на выполнение отдельных сервисных услуг регламентируется установленными национальными правилами и международными соглашениями $[1,4]$.

Так в депозитарии ИВМ обработка заявок на выдачу штаммов проходит в два этапа. На первом этапе принимается решение по полученной заявке, на втором выполняется принятое решение. При рассмотрении принятой заявки администрация депозитария обращает внимание на заявителя, цель использования им штамма, наличие условий и оборудования для работы со штаммом, учитывает ограничения на доступ к штамму в связи с патентной защитой и требования экологической безопасности. В случае принятия положительного решения на втором этапе происходит выдача штамма.

Если разрешение на выдачу штамма было получено, после обработки поданной заявки в базе данных сохраняется ее регистрационный номер и дата получения, ведомости о заявителе, оплате, дате выдачи штамма, его количестве и т.д.

Понятно, что большое внимание в депозитарии уделяют хранению штаммов [1]. Разноплановая информация относительно этой стороны работы депозитария сосредоточена в базе данных именно в блоке хранения.

В каталогах культур микроорганизмов есть мало информации о пребывании штамма в коллекции. Традиционно там указываются только оптимальная температура, среда культивирования и ее состав.

В депозитарии депозиторам рекомендуется еще в паспорте штамма указывать способ, условия, а также состав и среды культивирования, и среды для долгосрочного хранения штамма. Учитывая прежний опыт, администрация депозитария может высказать свои рекомендации по этому вопросу [3]. После того, как сделан согласованный выбор, в депозитарии начинается процесс хранения штамма и в базу данных заносится соответствующая информация.

В этой информации, когда говорится об условиях, то имеется в виду, например, прямое указание оптимальной концентрации ионов водорода - $\mathrm{pH}$, потребность в свободном молекулярном кислороде для процессов синтеза энергии принадлежность к определенному классу аэробов, потребность в облучении светом. Для каждого метода сообщается также и периодичность, с которой следует проводить закладки, чтобы достичь гарантированного срока хранения штамма.

В базе данных создается полный список всех сред, которые используются для культивирования и хранения штаммов, и приводится их состав.

Все закладки штаммов на хранение фиксируются в журнале хранения в базе данных. Здесь в каждой записи упоминается идентификатор штамма, порядковый 
номер закладки именно этого штамма во время пребывания в депозитарии, дата закладки, использованный метод хранения, количество единиц, заложенных на хранение, титр микроорганизма.

Все события, связанные с извлечением емкостей с микроорганизмами, которые находятся на хранении в депозитарии, фиксируются в базе данных в журнале использования. В каждой записи этого журнала указывается идентификатор штамма, порядковый номер закладки, из которой проведено извлечение, порядковый номер извлечения из этой закладки, дата события, количество извлеченных емкостей, цель их дальнейшего использования. Биологический материал из извлеченных емкостей может использоваться для проверки микроорганизма на жизнеспособность или аутентичность, выдачи на запрос, снятия с хранения и списания. Результаты проведенных проверок и сделанные выводы тоже заносятся в базу данных.

По записям в журнале хранения и журнале извлечения можно автоматически создать карту движения и состояния штамма в депозитарии.

Для удобства ввода и редактирования информации в базе данных построены формы разной сложности и организована кнопочная система навигации.

В базе данных создана система запросов, которая позволяет получать разноплановую информацию о деятельности администрации депозитария, общем состоянии коллекции и отдельных штаммов, предоставлении сервисных услуг.

Администрация депозитария взаимодействует с депозиторами, отвечает за полноту и своевременность документооборота между ними, отслеживает их активность. Она следит за численностью коллекции и изменениями в ее составе.

Система запросов позволяет выбирать штаммы по большинству показателей, перечисленных в описании штамма.

Анализируя карты учета движения и состояния штаммов за время пребывания в депозитарии, можно делать выводы об эффективности использования методов культивирования и хранения штаммов относительно разных видовых таксонов.

Дружественный интерфейс пользователя с базой данных обеспечивают разработанные на основе запросов формы и отчеты. Среди них и доступные внешнему пользователю упорядоченные по типам и видам общий список штаммов, нумерический индекс и каталог культур.

Поисковая система позволяет внешнему пользователю получить информацию о штамме в объеме каталога, если ему известно хотя бы одно название вида (указанное в паспорте, данное администрацией депозитария, синонимическое) или хотя бы один идентификатор штамма (указанный в паспорте, присвоенный администрацией депозитария, полученный в другой коллекции).

Проектирование базы данных для депозитария культур микроорганизмов велось с использованием СУБД MS Access 2010.

\author{
Броварник B.В. ${ }^{1}$ Головач T.M. ${ }^{2}$ \\ ${ }^{1}$ Науково-учбовий иентр прикладной інформатики НАН Украйни, Київ, \\ ${ }^{2}$ Інститут мікробіологї і вірусології ім. Д.К.Заболотного НАН Украйни, Кийв
}

\title{
БАЗА ДАНИХ ДЛЯ ДЕПОЗИТАРІЮ КУЛЬТУР МІКРООРГАНПЗМІВ
}

\author{
P е 3 ю м е
}

Розроблено з використанням СКДБ MS Access 2010 базу даних (БД) депозитарію культур мікроорганізмів. Ядро БД складають три основні модулі: загального опису, 
адміністрування, зберігання. Наводиться опис інформації, що міститься в кожному 3 цих модулів, для вирішення характерних для ведення депозитарію задач. На основі БД розробляється веб-сторінка депозитарію.

Кл ю ч о в і сл о в а: мікроорганізми, колекція, депозитарій, база даних.

\author{
Brovarnyk V. ${ }^{1}$ Golovach T.M. ${ }^{2}$ \\ ${ }^{I}$ Training Center of Applied Informatics, NAS of Ukraine, Kyiv \\ ${ }^{2}$ Zabolotny Institute of Microbiology and Virology, NAS of Ukraine, Kyiv
}

\title{
DATABASE FOR DEPOSITARY DEPARTMENT OF MICROORGANISMS
}

S u $\mathrm{m} \mathrm{m}$ a $\mathrm{r} \mathrm{y}$

The database on microorganism culture depositary is designed with using MS Access 2010. Three major modules, namely general description, administration, storage, compound database kernel. Description of information in these modules is given. Web page of the depositary is developed on the database.

Ke y w ords: microorganisms, collection, depositaries, database.

The author's address: V. Brovarnyk, Training center of applied Informatics of the NAS of Ukraine, 40 Acad. Glushkov Avenue, Kyiv, Ukraine. sbrov@yahoo.com.

1. Головач Т.Н., Підгорський В.С., Суденко В.І., Грома Л.І. Депонування та зберігання інноваційних мікроорганізмів. - Методичні рекомендації. Київ: Знання України, 2004. - 108 стор.

2. Головач T.M. Патентное депонирование биоматериалов и Конвенция ООН о сохранении биологического разнообразия. - 10-я международная научно-практическая конференция «Актуальные проблемы охраны интеллектуальной собственности». - Алушта 11-15 сентября 2006. - С. 84-88.

3. Головач Т.Н., Грома Л.И. Влияние криоконсервации и лиофилизации на синтез екзополисахарида и жизнеспособность Xantomonas campestris pv. Campestris IMB В-7001// Мікробіол. журн. - 2013. - 75, №1. - С. 14-20.

4. Інструкиія про порядок депонування в Україні штамів мікроорганізмів з метою здійснення патентної прочедури. - Введ. 26.06.95. - Держреєстрація 04.08.95, № 286/822.

5. Порядок депонування итамів мікроорганізмів, які використовують для виробництва біonpenapamiв. - Наказ Головного Державного інспектора ветеринарної медицини України від 17.01.01 № 5 .

6. Про державну систему депонування итамів мікроорганізмів. - Постанова Кабінету Міністрів України від 12.10.1994 р. № 705.

Отримано 17.05.2014 